Key Words: Grout Formulation

Salt Waste Stabilization

Liquid Waste Disposal

\title{
TANK 50 BATCH 0 SALTSTONE FORMULATION CONFIRMATION (U)
}

\author{
C. A. Langton, E. K. Hansen, P. R. Burket,
} D. M. Marsh, D. P. Healy, J. G. Wheeler

Savannah River National Laboratory Westinghouse Savannah River Company

Aiken, SC 29809

June 5, 2006

Westinghouse Savannah River Company

Savannah River Site

Aiken, SC 29808

Prepared for the U.S. Department of Energy Under

Contract Number DE-AC09-96SR18500

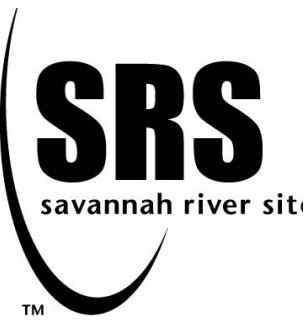




\section{DISCLAIMER}

This report was prepared for the United States Department of Energy under Contract No. DE-AC09-96SR18500 and is an account of work performed under that contract. Reference herein to any specific commercial product, process, or service by trademark, name, manufacturer, or otherwise does not necessarily constitute or imply endorsement, recommendation, or favoring of same by Washington Savannah River Company or by the United States Government or any agency thereof. The views and opinions of the authors expressed herein do not necessarily state or reflect those of the United States Government or any agency thereof.

Printed in the United States of America

Prepared For

U.S. Department of Energy 
TANK 50 BATCH O SALTSTONE FORMULATION CONFIRMATION (U)

June 5, 2006

Westinghouse Savannah River Company Savannah River Site

Aiken, SC 29808

Prepared for the U.S. Department of Energy Under Contract Number DE-AC09-96SR18500

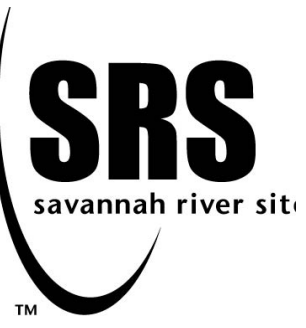


WSRC-TR-2006-00226 Revision 0

June 5, 2006

PREVIEWS AND APPROVALS

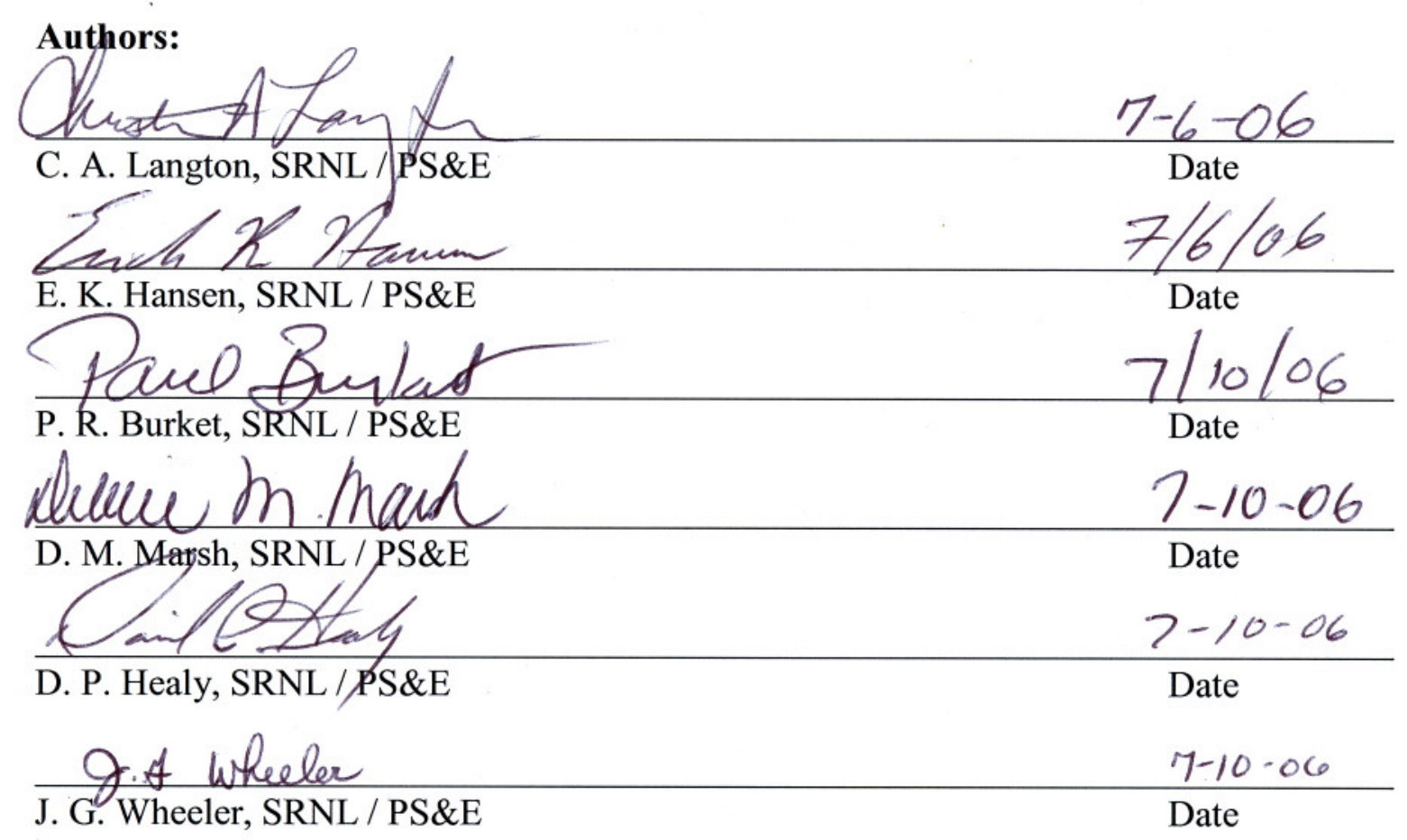

Reviewers:

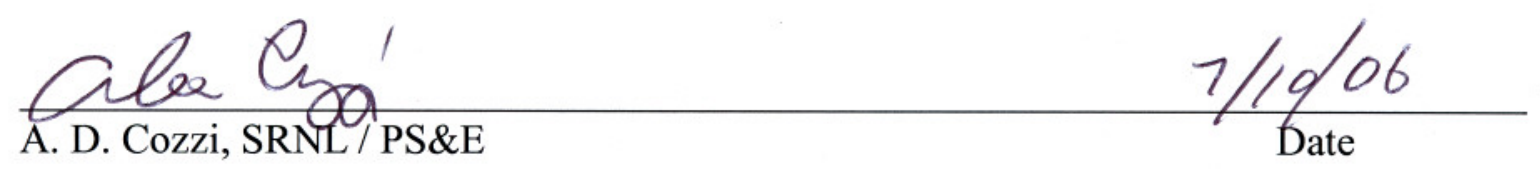

Approvers:
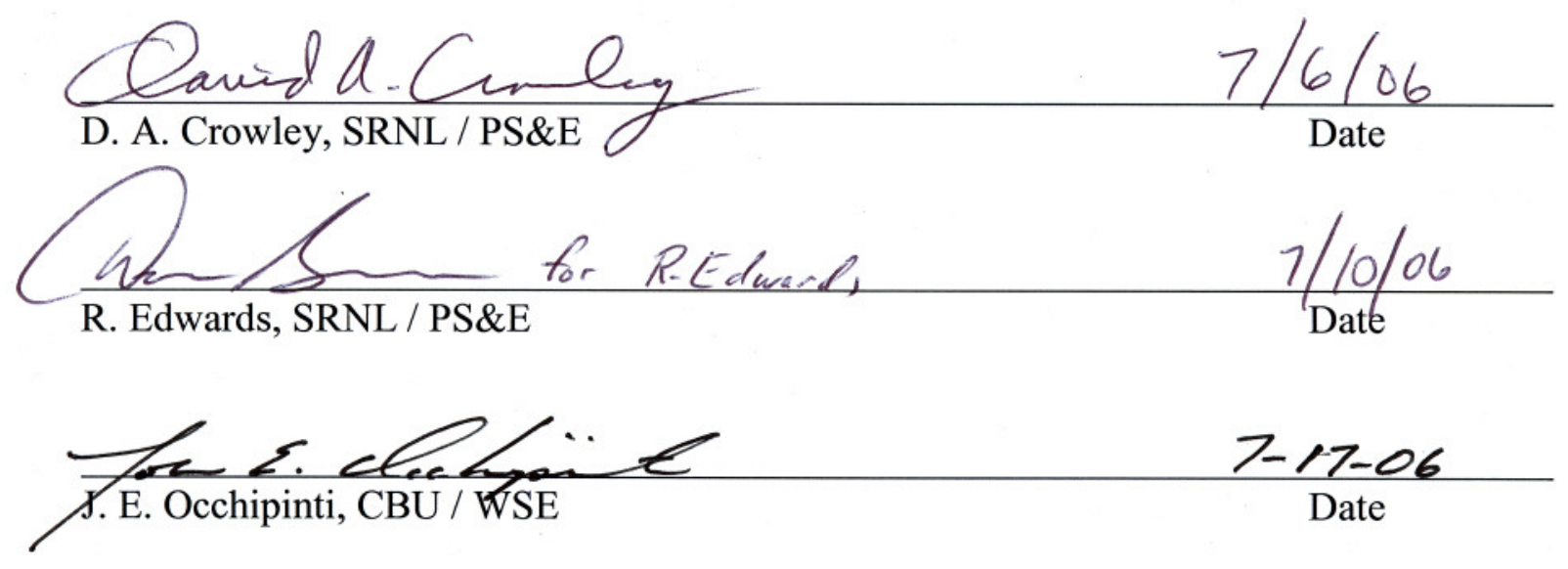


\section{TABLE OF CONTENTS}

\section{REVIEWS AND APPROVALS}

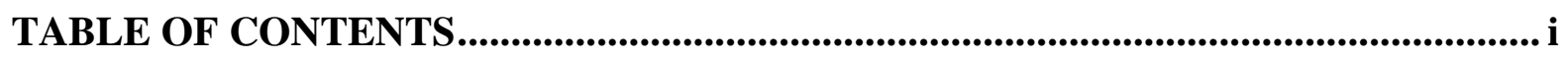

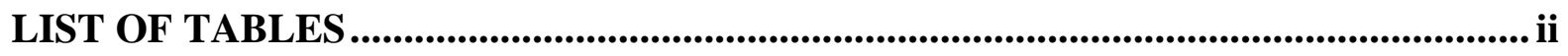

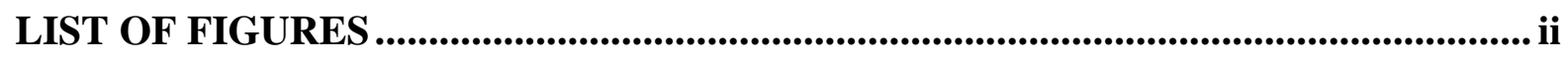

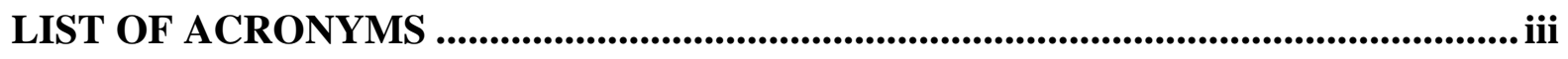

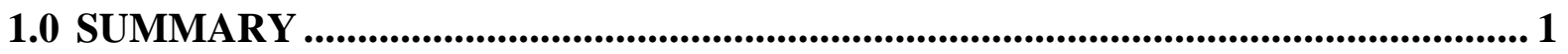

2.0 TANK 50 CHARACTERIZATION RESULTS ....................................................... 2

2.1 Tank 50 Sample Receipt and Characterization ............................................ 2

3.0 SALTSTONE SLURRY PREPARATION AND TESTING RESULTS .................. 5

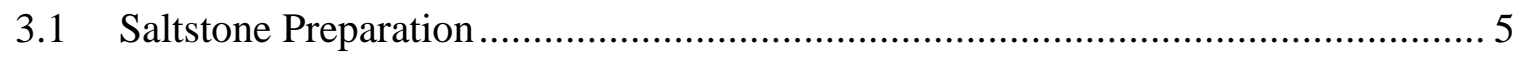

3.2 Saltstone Slurry CharacterizationPreparation .............................................. 6

4.0 CONCLUSIONS AND RECOMMENDATIONS ........................................... 18

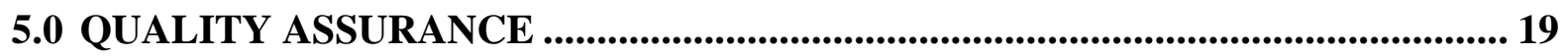

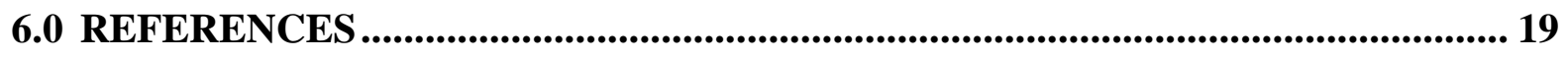




\section{LIST OF TABLES}

TABLE 2-1. DENSITY OF THE TANK 50 BATCH 0 MAY 2006 SAMPLE. .3

TABLE 2-2. SOLIDS CONTENT IN THE TANK 50 BATCH 0 MAY 2006 SAMPLE. 4

TABLE 3-1. SALTSTONE FORMULATION RECOMMENDED FOR THE SEPTEMBER 2005 SAMPLE OF TANK 50 BATCH 0 [4].

TABLE 3-2. PLASTIC VISCOSITY AND YIELD STRESS RESULTS AT VARIOUS WATER/PREMIX RATIOS AND DARATARD 17 DOSES.

TABLE 3-3. GEL TIME RESULTS FOR VARIOUS WATER/PREMIX RATIOS AND DARATARD 17 DOSES.

TABLE 3-4. DENSITY, BLEED WATER, AND SET TIME RESULTS FOR TANK 50 BATCH 0 SALTSTONE TEST MIXES.

\section{LIST OF FIGURES}

FIGURE 1-1. SALTSTONE FORMULATION BASED ON TANK 50 SAMPLE COLLECTED IN MAY 2006.......

FIGURE 2-1. SAMPLES OF TANK 50 BATCH 0 COLLECTED MAY 17, 2006 AND IN SEPTEMBER 2005.

FIGURE 2-2. COMPOSITED TANK 50 BATCH 0 MAY 2006 SAMPLE ONE DAY AFTER COMBINING THE THREE ONE LITER SAMPLES.

FIGURE 3-1. FLOW CURVES FOR (A) BASELINE MIX PREPARED WITH TANK 50 BATCH 0 SAMPLE COLLECTED IN SEPTEMBER 2005 AND FOR TEST MIXES WITH WATER/PREMIX $=0.63$ (B, C, AND D) PREPARED WITH TANK 50 BATCH 0 SAMPLE COLLECTED IN MAY 2006 WITH DARATARD 17 DOSES OF 1X, 2X AND 1.5X, RESPECTIVELY.

FIGURE 3-2. FLOW CURVES FOR SALTSTONE TEST MIXES PREPARED WITH TANK 50 BATCH 0 SAMPLE COLLECTED IN MAY 2006 AS A FUNCTION OF DARATARD 17 DOSE, (A) AND (B), AND AS A FUNCTION OF WATER TO PREMIX RATIO, (C) AND (D).

FIGURE 3-3. VANE MEASUREMENTS USING A ROTO VISCOMETER DATA FOR SALTSTONE SLURRIES PREPARED WITH THE MAY 2006 TANK 50 BATCH 0 SOLUTION AND A WATER/PREMIX RATIO OF 0.63 AS A FUNCTION OF DARATARD 17 DOSE.

FIGURE 3-4. VANE MEASUREMENTS USING A ROTO VISCOMETER DATA FOR SALTSTONE SLURRIES PREPARED WITH THE MAY 2006 TANK 50 BATCH 0 SOLUTION AND A DARATARD DOSE OF 1.5X AS A FUNCTION OF WATER/PREMIX RATIO.

FIGURE 3-5. VISUAL OBSERVATIONS OF MIXES IMMEDIATELY AFTER MIXING AND AFTER TERMINATION OF THE VANE GEL TIME MEASUREMENTS. 


\section{LIST OF ACRONYMS}

$\begin{array}{ll}\text { AD } & \text { Analytical Development } \\ \text { cP } & \text { centipoise } \\ \text { CST } & \text { Chemical Science and Technology } \\ \text { DOE } & \text { United States Department of Energy } \\ \text { DS } & \text { Dissolved Solids } \\ \text { DSS } & \text { Dissolved Supernate Solids } \\ \text { ETP } & \text { Effluent Treatment Project } \\ \text { g } & \text { gram } \\ \text { H-CAN } & \text { H-Canyon } \\ \text { HEU } & \text { Highly Enriched Uranium } \\ \text { IS } & \text { Insoluble Solids } \\ \text { mL } & \text { milliliter } \\ \text { Pa } & \text { Pascal } \\ \text { PS\&E } & \text { Process Science and Technology } \\ \text { SRNL } & \text { Savannah River National Laboratory } \\ \text { SRS } & \text { Savannah River Site } \\ \text { TS } & \text { Total Solids } \\ \text { TT/QAP } & \text { Technical Task and Quality Assurance Plan } \\ \text { TTR } & \text { Technical Task Request } \\ \text { WSE } & \text { Waste Solidification Engineering } \\ \text { WSRC } & \text { Washington Savannah River Company } \\ \text { Wt } & \text { Weight } \\ \text { Wt\% } & \text { Weight percent }\end{array}$


WSRC-TR-2006-00226 Revision 0

June 5, 2006

Page iv

\section{THIS PAGE INTENTIONALY LEFT BLANK}




\subsection{SUMMARY}

Savannah River National Laboratory (SRNL) personnel were requested to confirm the Tank 50 Batch 0 grout formulation per Technical Task Request, SSF-TTR-2006-0001 (task 1 of 2) [1]. Earlier Batch 0 formulation testing used a Tank 50 sample collected in September 2005 and is described elsewhere [2]. The current testing was performed using a sample of Tank 50 waste collected in May 2006. This work was performed according to the Technical Task and Quality Assurance Plan (TT/QAP), WSRC-RP-2006-00594 [3].

The salt solution collected from Tank 50 in May 2006 contained approximately 3 weight percent more solids than the sample collected in September 2005. The insoluble solids took longer to settle in the new sample which was interpreted as indicating finer particles in the current sample.

The saltstone formulation developed for the September 2005 Tank 50 Batch 0 sample was confirmed for the May 2006 sample with one minor exception. Saltstone prepared with the Tank 50 sample collected in May 2006 required 1.5 times more Daratard 17 set retarding admixture than the saltstone prepared with the September 2005 sample to achieve similar gel times for water to premix ratios between 0.60 and 0.65 .

Figure 1-1. Saltstone Formulation Based on Tank 50 Sample Collected in May 2006.

\begin{tabular}{|l|c|c|}
\hline Ingredient & \multicolumn{2}{|c|}{ Weight Percent of Total } \\
\hline Premix (10/45/45 Mix) & 53.4 & -- \\
\hline Cement & -- & 5.34 \\
\hline Slag & -- & 24.03 \\
\hline Fly Ash & -- & 24.03 \\
\hline Salt Solution & 46.6 & 0 \\
\hline Water & -- & 33.64 \\
\hline Waste Solids & -- & 12.96 \\
\hline Total & 100 & 100 \\
\hline Daratard 17 Set Retarder & $0.27 \mathrm{wt} \%$ of Premix \\
\hline Clear Air 100 Defoamer/Antifoaming agent & $0.13 \mathrm{wt} \%$ of Premix \\
\hline Water to Premix mass ratio (Target for initial run) & \multicolumn{2}{|c|}{0.630} \\
\hline $\begin{array}{l}\text { Target Operating Range for Batch 0 Saltstone Water } \\
\text { to Premix range }\end{array}$ & \multicolumn{2}{|c|}{$+/-0.015$} \\
\hline
\end{tabular}

In addition, a sample prepared with lower shear mixing (stirring with a spatula) had a higher plastic viscosity $(57 \mathrm{cP})$ than samples made with higher shear mixing in a blender $(23 \mathrm{cP})$. The static gel times of the saltstone slurries made with low shear mixing were also shorter $(\sim 32$ minutes) than those for comparable samples made in the blender ( 47 minutes).

The addition of the various waste streams (ETP, HEU-HCAN, and GPE-HCAN) to Tank 50 from September 2005 to May 2006 has increased the amount of set retarder, Daratard 17, required for processing saltstone slurries through the Saltstone facility. If these streams are continued to be added to Tank 50, the quantity of admixtures required to maintain the same processing conditions for the Saltstone facility will probably change and additional testing is recommended to reconfirm the Tank 50 Saltstone formulation. 


\subsection{TANK 50 CHARACTERIZATION RESULTS}

Page 2 of 19

\subsection{Tank 50 Sample Receipt and Characterization}

Three 1-L samples of Tank 50 Batch 0 salt solution were collected on May 17, 2006 per Sample Request, CST-2006-00016 [4]. The samples were photographed at SRNL prior to compositing and are shown in Figure 2-1. The three samples were similar to each other but distinctly different from the sample collected in September 2005. The new samples contained more insoluble solids which required more time to settle compared to the September 2005 sample. The longer settling time is at least in part attributed to finer particles. The composited May 2006 sample is shown in Figure 2-2 after settling for 17 hours. The settled solids make up approximately 13.5 volume percent of the total composite sample. The $\mathrm{pH}$ of the composite sample was 14 or higher.

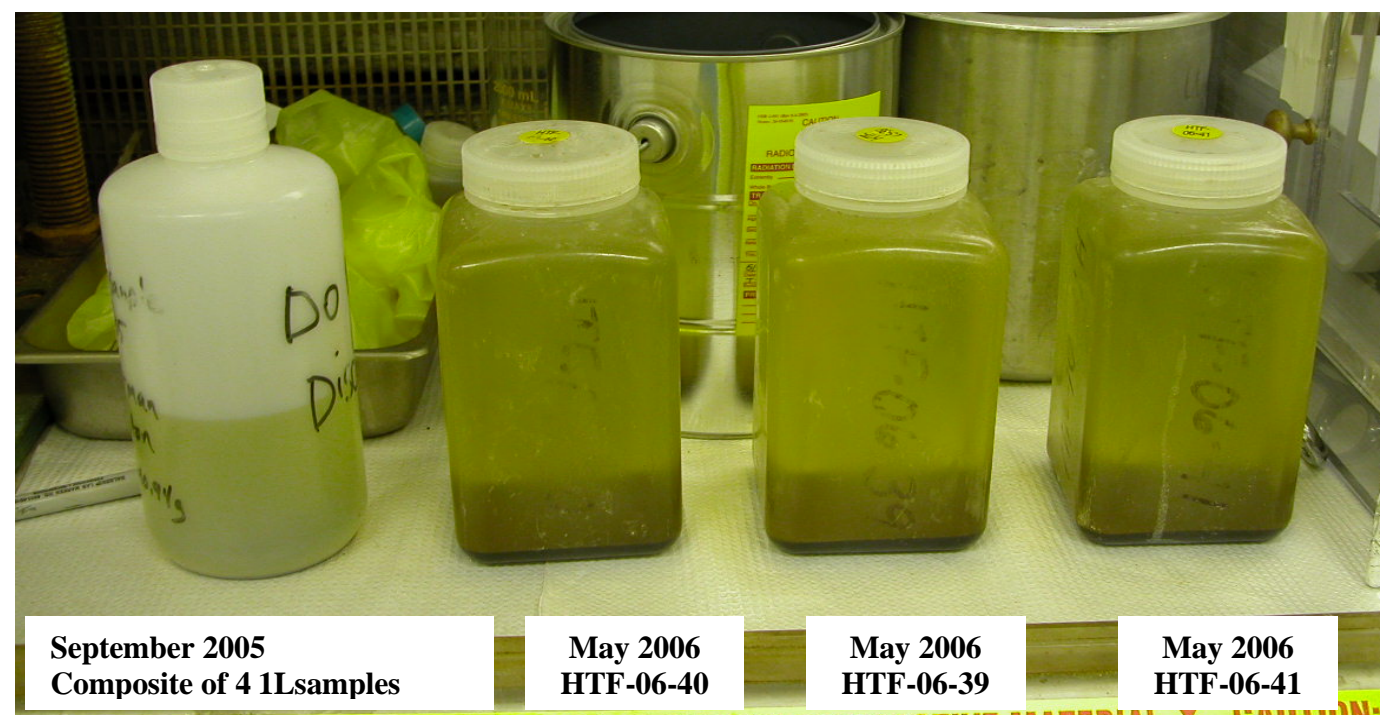

Figure 2-1. Samples of Tank 50 Batch 0 collected May 17, 2006 and in September 2005.

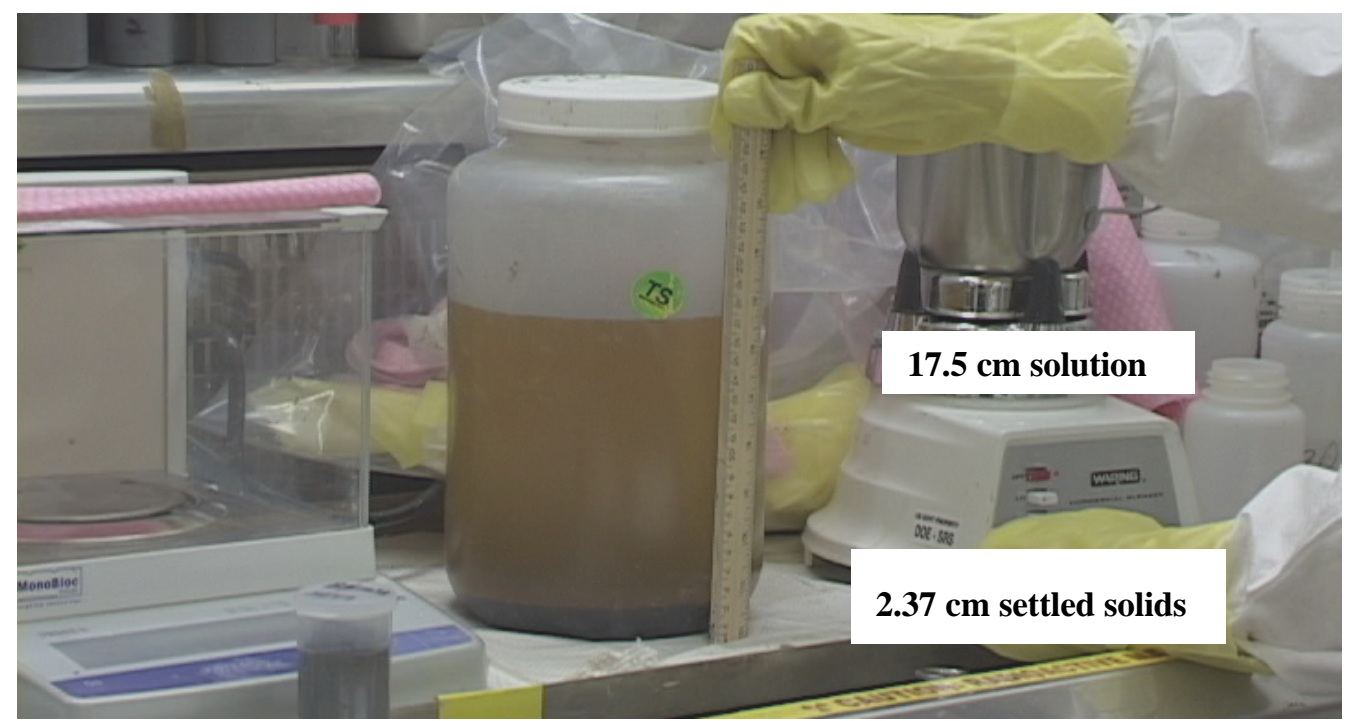

Figure 2-2. Composited Tank 50 Batch 0 May 2006 sample one day after combining the three one liter samples. 
The densities and weight percent solids of the composite sample and of the filtered composite sample (supernate) are listed in Tables 1 and 2, respectively. The densities were initially measured using a water calibrated $10 \mathrm{~mL}$ syringe. The density measurements were repeated using $10 \mathrm{~mL}$ Gay-Lussac bottles for both the composited sample and supernate solution. The density of the current composite Tank 50 sample and supernate were greater than the density of the Tank 50 sample collected in September $2005(1.197 \mathrm{~g} / \mathrm{mL})$.

Table 2-1. Density of the Tank 50 Batch 0 May 2006 sample.

\begin{tabular}{|r|c|c|c|c|}
\cline { 2 - 5 } & \multicolumn{4}{|c|}{ Density $(\mathbf{g} / \mathbf{m l})$} \\
\cline { 2 - 5 } Measurement & Calibrated Syringe Method & \multicolumn{2}{c|}{ Guy Lussac Bottle Method } \\
\cline { 2 - 5 } & Composite & Supernate & Composite & Supernate \\
\hline 1 & 1.2188 & 1.2164 & 1.2512 & 1.2345 \\
\hline 2 & 1.2197 & 1.2115 & 1.2522 & 1.2335 \\
\hline Average & 1.2193 & 1.2140 & 1.2520 & 1.2340 \\
\hline $\begin{array}{r}\text { Standard } \\
\text { Deviation }\end{array}$ & 0.0006 & 0.0035 & 0.0003 & 0.0007 \\
\hline
\end{tabular}

Initially, the total solids (TS) and dissolved supernate solids (DSS) were obtained using a Moisture Analyzer which utilized a heat lamp to evaporate the water from the sample. Using this technique, the water content of the Batch 0 composite sample was approximately 70 weight percent which was the value used for determining the test formulations. Subsequently, the total solids and the dissolved solids in the supernate were determined by drying the samples at $105^{\circ} \mathrm{C}$ overnight to constant weight using the drying oven method. The drying oven method removed about one weight percent more water from the supernate and about one weight percent less water from the total solids than the Moisture Analyzer.

The weight percent insoluble solids (IS) and the weight \% soluble solids were calculated using the average measurements for the TS and DSS values obtained from the ADS Oven Drying Method using the equations shown below. Results are presented in Table 2-2.

$\mathrm{W}_{\mathrm{IS}}=\left(\mathrm{W}_{\mathrm{TS}}-\mathrm{W}_{\mathrm{DS}}\right) /\left(1-\mathrm{W}_{\mathrm{DS}}\right) \quad$ and $\quad \mathrm{W}_{\mathrm{SS}}=\mathrm{W}_{\mathrm{TS}}-\mathrm{W}_{\mathrm{IS}}$

Where:

$\mathrm{W}_{\mathrm{IS}}=$ Weight fraction of insoluble solids in the slurry

$\mathrm{W}_{\mathrm{SS}}=$ Weight fraction of soluble solids in the slurry

$\mathrm{W}_{\mathrm{TS}}=$ Weight fraction of total solids in the slurry

$\mathrm{W}_{\mathrm{DS}}=$ Weight fraction of dissolved solids in the filtered supernate

Thus:

$\mathrm{Wt} \%$ dissolved solids $=$ $\mathrm{Wt} \%$ total solids $=$ $\mathrm{Wt} \%$ insoluble solids = $\mathrm{Wt} \%$ soluble solids $=$ (wt dissolved solids/wt of supernate) X 100 (wt total solids/wt of the total slurry) X 100 (wt insoluble solids/wt of total slurry) X 100 (wt of dissolved solids/wt of total slurry) X 100 
WSRC-TR-2006-00226 Revision 0

June 5, 2006

Page 4 of 19

Table 2-2. Solids Content in the Tank 50 Batch 0 May 2006 sample.

\begin{tabular}{|c|c|c|c|c|c|c|}
\hline \multirow[b]{3}{*}{ Measurement } & \multicolumn{6}{|c|}{$\begin{array}{c}\text { Total Solids, Dissolved Solids in the Supernate, and Insoluble Solids } \\
\text { (Weight Percent) }\end{array}$} \\
\hline & \multicolumn{3}{|c|}{ Moisture Analyzer } & \multicolumn{3}{|c|}{ ADS Drying Oven } \\
\hline & $\begin{array}{l}\text { Total } \\
\text { Solids }\end{array}$ & $\begin{array}{l}\text { Dissolved } \\
\text { Solids in } \\
\text { Supernate }\end{array}$ & Insoluble & Total Solids & $\begin{array}{l}\text { Dissolved } \\
\text { Solids in } \\
\text { Supernate }\end{array}$ & Insoluble \\
\hline 1 & 29.98 & 29.80 & - & 31.07 & 29.06 & - \\
\hline 2 & 30.01 & 29.94 & - & 31.15 & 28.88 & - \\
\hline Average & 30.00 & 29.87 & 0.18 & 31.11 & 28.97 & 3.01 \\
\hline $\begin{array}{l}\text { Standard } \\
\text { Deviation }\end{array}$ & 0.02 & 0.10 & - & 0.06 & 0.13 & - \\
\hline
\end{tabular}

Note: The weight percent total solids of the Tank 50 Batch 0 sample collected in September 2005 was 27.8 wt. $\%$.

The average density of the insoluble solids was calculated to be $2.36 \mathrm{~g} / \mathrm{mL}$. The Guy Lussac Bottle density data for the composite and supernate and the drying oven weight percent solids data were used to calculate the density of the average insoluble solids. The following equation was used to calculate the average density of the insoluble fraction.

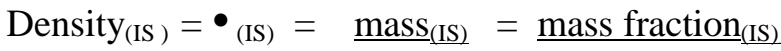

$$
\operatorname{vol}_{(\mathrm{IS})} \quad \text { vol per unit mass }\left(\text { total) } - \text { vol per unit mass } \left(_{(\text {everything but insolubles) }}\right.\right.
$$

Where:

Total volume per unit mass $=\frac{1}{\bullet \text { (total) }} \quad$ (The numerator is the total mass fraction and is equal to 1.)

Volume per unit mass ${ }_{(\text {everything but insolubles) }}=\underline{1-\text { mass fraction }_{(\mathrm{IS})}}$

- (supernate) 


\subsection{SALTSTONE SLURRY PREPARATION AND TESTING RESULTS}

\subsection{Saltstone Preparation}

Type I/II portland cement (Holly Hill SC, Holcim Inc.), Grade 100 slag cement (Birmingham AL, Holcim Inc.), and Class F fly ash (Cross Station Power Plant) used in this formulation confirmation testing were obtained from Z-Area in May 2006. The weight percentages of these ingredients used to prepare the premix for the confirmation testing were 10, 45, and 45, respectively.

The batch size was based on 400 grams of premixed reagents (40 grams of cement, 180 grams of slag and 180 grams of fly ash). Water to premix mass ratio was used as the parameter for proportioning the various test mixes. The amount of Tank 50 waste solution in each test mix was proportioned on the basis of the amount of water in the solution required to achieve the intended water to premix ratio. The mixing water is the evaporable water in the salt solution (1 minus the weight percent total solids in the salt solution.)

All of the saltstone mixes prepared in this study were proportioned assuming 70 weight percent water in the May 2006 Tank 50 Batch 0 sample. Mixes were prepared with water to premix ratios between 0.60 and 0.65 . Daratard 17 (set retarder manufactured by W. R. Grace, Inc.) and Clear Air 100 (supplied by Clearwater International Group) were used in the testing per the TT/QAP [2].

Saltstone mixes were prepared in a blender by mixing at low speed for one minute followed by mixing at high speed for two minutes. Admixtures were added to the salt solution prior to adding the cementitious premix. One mix was prepared by stirring with a spatula in a beaker rather than by mixing in a blender to bracket the mechanical shear conditions that could be encountered in the actual mixing process. A portion of each mix was used for rheological measurements. The remainder of the mix was cast into plastic containers for bleed water and set time determinations. The densities of the saltstone slurries were also measured.

The formulation recommended for the Tank 50 Batch 0 sample collected in Septermber 2005 was used as the baseline and is provided in Table 3-1. The Daratard 17 and Clear Air doses in this formulation are referred to as the $1 \mathrm{X}$ doses. The amount of Clear Air 100 defoamer was not adjusted in this series of tests because the $1 \mathrm{X}$ dose appeared to eliminate air entrapment in the saltstone slurries. However, because the gel time of the initial mix containing a $1 \mathrm{X}$ dose of Daratard 17 was short, testing as a function Daratard 17 was performed. 
Table 3-1. Saltstone formulation recommended for the September 2005 sample of Tank 50 Batch 0 [4].

\begin{tabular}{|l|c|c|}
\hline Ingredient & \multicolumn{2}{|c|}{ Weight Percent of Total } \\
\hline Premix (10/45/45 Mix) & 53.4 & -- \\
\hline Cement & -- & 5.34 \\
\hline Slag & -- & 24.03 \\
\hline Fly Ash & -- & 24.03 \\
\hline Salt Solution & 46.6 & -- \\
\hline Water & -- & 33.64 \\
\hline Waste Solids & -- & 12.96 \\
\hline Total & 100 & 100 \\
\hline Daratard 17 Set Retarder & $0.18 \mathrm{wt} \%$ of Premix \\
\hline $\begin{array}{l}\text { Defoamer/Antifoaming agent } \\
\text { Clear Air 100 (most effective } \\
\text { defoamer tested but not miscible with } \\
\text { Daratard 17) }\end{array}$ & $0.13 \mathrm{wt} \%$ of Premix \\
\hline $\begin{array}{l}\text { Water to Premix mass ratio } \\
\text { (Target for initial run) }\end{array}$ & \multicolumn{2}{|c|}{0.630} \\
\hline $\begin{array}{l}\text { Target Operating Range for Batch 0 } \\
\text { Saltstone Water to Premix range }\end{array}$ & \multicolumn{2}{|c|}{0.615} \\
& $+/-0.015$ \\
\hline
\end{tabular}

\subsection{Saltstone Slurry CharacterizationPreparation}

\subsubsection{Rheological Properties}

Flow curves were obtained using a Haake rotoviscometer equipped with a stationary sample cup (outer cylinder) and a rotating MVII bob (inner cylinder). This instrument used a smooth wall coaxial cylindrical geometry. The flow in the annular gap between the two concentric cylinders was characterized by measuring the torque and speed of the inner cylinder. The torque readings were converted to shear stress and the speed to shear rate.

Flow curves (up and down) were generated over a shear rate range of 0 to $300 \mathrm{sec}^{-1}$. Each curve took two minutes to accelerate/decelerate. After accelerating to $300 \mathrm{sec}^{-1}$, the shear rate was held for 30 seconds prior to decelerating. Flow curves were generated for fresh Saltstone slurry samples immediately after the sample was transferred from the mixing hood to the rheology hood located about 8 feet apart. Based on the shapes of the down curve, a rheological model was used for regression of the data.

The Bingham Plastic rheological model was used to calculate the plastic viscosity and yield stress of each of the Saltstone slurries tested. Equations used to calculate the plastic viscosity and yield stress using the flow curve data are presented elsewhere [5]. For this study, plastic viscosities and yield stresses were calculated from the data on the decreasing shear rate portions of the flow curves. Plastic viscosity and yield stress values are summarized in Table 3-2. The flow curves are provided in Figures 3-1 and 3-2. 
Table 3-2. Plastic viscosity and yield stress results at various water/premix ratios and Daratard 17 doses.

\begin{tabular}{|c|c|c|c|c|c|c|c|}
\hline Sample & $\mathbf{w} / \mathbf{p}$ & $\begin{array}{l}\text { Daratard } 17 \\
\text { (X reference) }\end{array}$ & \begin{tabular}{|c|} 
Clear Air \\
100 \\
(X reference)
\end{tabular} & $\begin{array}{c}\text { Yield } \\
\text { Stress } \\
(\mathbf{P a}) \\
\end{array}$ & $\begin{array}{c}\text { Plastic } \\
\text { Viscosity } \\
\text { (cP) }\end{array}$ & $\mathbf{R}^{2}$ & Comments \\
\hline $\begin{array}{l}\text { B0S63R } \\
\text { Baseline }\end{array}$ & 0.63 & $\begin{array}{l}0.18 \text { wt. } \% \\
\text { premix } \\
(1 \mathrm{X})\end{array}$ & $\begin{array}{l}0.13 \text { wt. } \% \\
\text { premix } \\
(1 \mathrm{X})\end{array}$ & 1.76 & 23.3 & 0.9991 & $\begin{array}{l}\text { Reference Sept. } \\
2005 \\
\text { Tank } 50 \text { sample, } \\
\text { Blender mixing }\end{array}$ \\
\hline B0M63A & 0.63 & $\begin{array}{l}0.18 \text { wt. } \% \\
\text { premix } \\
(1 \mathrm{X})\end{array}$ & $\begin{array}{c}\text { Same as } \\
\text { above }\end{array}$ & 2.66 & 24.6 & 0.9991 & $\begin{array}{l}\text { May } 2006 \\
\text { Tank } 50 \text { sample, } \\
\text { Blender mixing }\end{array}$ \\
\hline B0M63B & 0.63 & $\begin{array}{l}0.36 \mathrm{wt} . \% \\
\text { premix } \\
(2 \mathrm{X})\end{array}$ & $\begin{array}{c}\text { Same as } \\
\text { above }\end{array}$ & 1.34 & 24.0 & 0.9927 & $\begin{array}{l}\text { May } 2006 \\
\text { Tank } 50 \text { sample, } \\
\text { Blender mixing }\end{array}$ \\
\hline B0M63C & 0.63 & $\begin{array}{l}0.27 \text { wt. \% } \\
\text { premix } \\
(1.5 \mathrm{X})\end{array}$ & $\begin{array}{c}\text { Same as } \\
\text { above }\end{array}$ & 1.72 & 23.4 & 0.9980 & $\begin{array}{l}\text { May } 2006 \\
\text { Tank } 50 \text { sample, } \\
\text { Blender mixing }\end{array}$ \\
\hline B0M63D & 0.63 & $\begin{array}{c}0.315 \text { wt. \% } \\
\text { premix } \\
(1.75 \mathrm{X})\end{array}$ & $\begin{array}{l}\text { Same as } \\
\text { above }\end{array}$ & 1.25 & 23.1 & 0.9988 & $\begin{array}{l}\text { May } 2006 \\
\text { Tank } 50 \text { sample, } \\
\text { Blender mixing }\end{array}$ \\
\hline B0M63E & 0.63 & $\begin{array}{c}0.27 \text { wt. } \% \\
\text { premix } \\
(1.5 \mathrm{X}) \\
\end{array}$ & $\begin{array}{l}\text { Same as } \\
\text { above }\end{array}$ & 1.14 & 57.5 & 0.9997 & $\begin{array}{l}\text { May } 2006 \\
\text { Tank } 50 \text { sample, } \\
\text { Hand mixed }\end{array}$ \\
\hline B0M60 & 0.60 & $\begin{array}{l}0.27 \text { wt. } \% \\
\text { premix } \\
(1.5 \mathrm{X})\end{array}$ & $\begin{array}{l}\text { Same as } \\
\text { above }\end{array}$ & 2.10 & 26.9 & 0.9988 & $\begin{array}{l}\text { May } 2006 \\
\text { Tank } 50 \text { sample, } \\
\text { Blender mixing }\end{array}$ \\
\hline B0M65 & 0.65 & $\begin{array}{l}0.27 \text { wt. } \% \\
\text { premix } \\
(1.5 \mathrm{X}) \\
\end{array}$ & $\begin{array}{l}\text { Same as } \\
\text { above }\end{array}$ & 1.54 & 22.6 & 0.9988 & $\begin{array}{l}\text { May } 2006 \\
\text { Tank } 50 \text { sample, } \\
\text { Blender mixing }\end{array}$ \\
\hline
\end{tabular}

Colored shading indicates 1) the Baseline formulation and 2) the formulation made with the May 2006 Tank 50 Batch 0 sample that most closely resembles the baseline mix. All mixes were made with the current premix ingredients and the September 2005 Tank 50 sample. 
WSRC-TR-2006-00226 Revision 0

June 5, 2006

Page 8 of 19

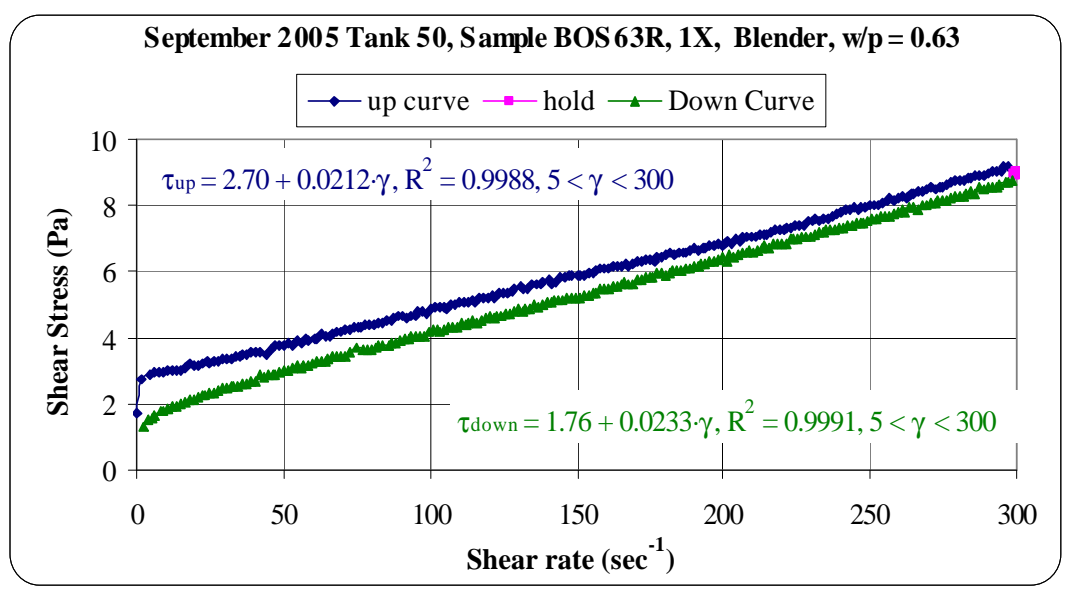

(a)

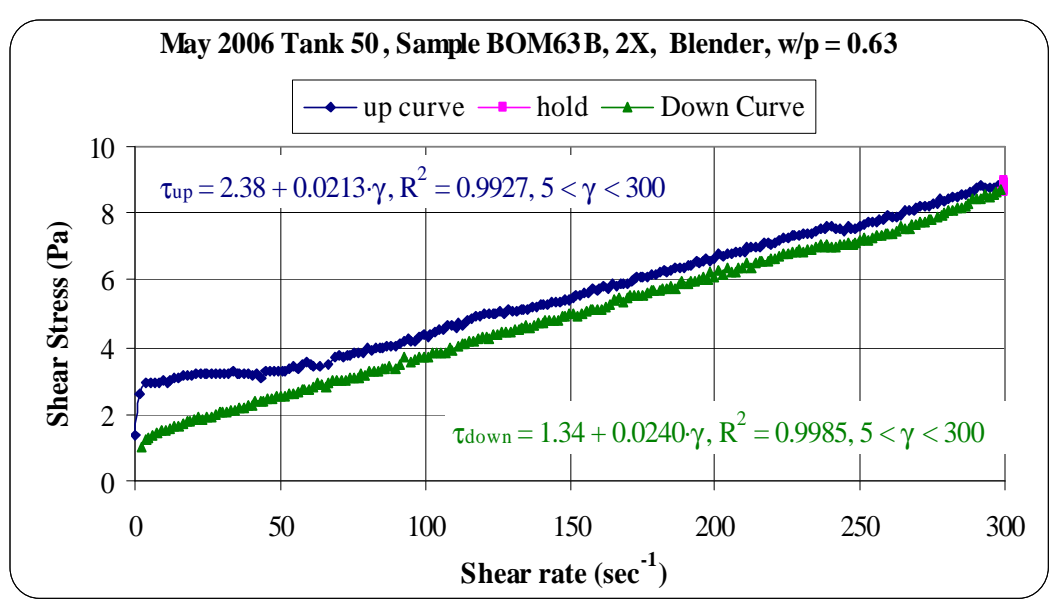

(c)

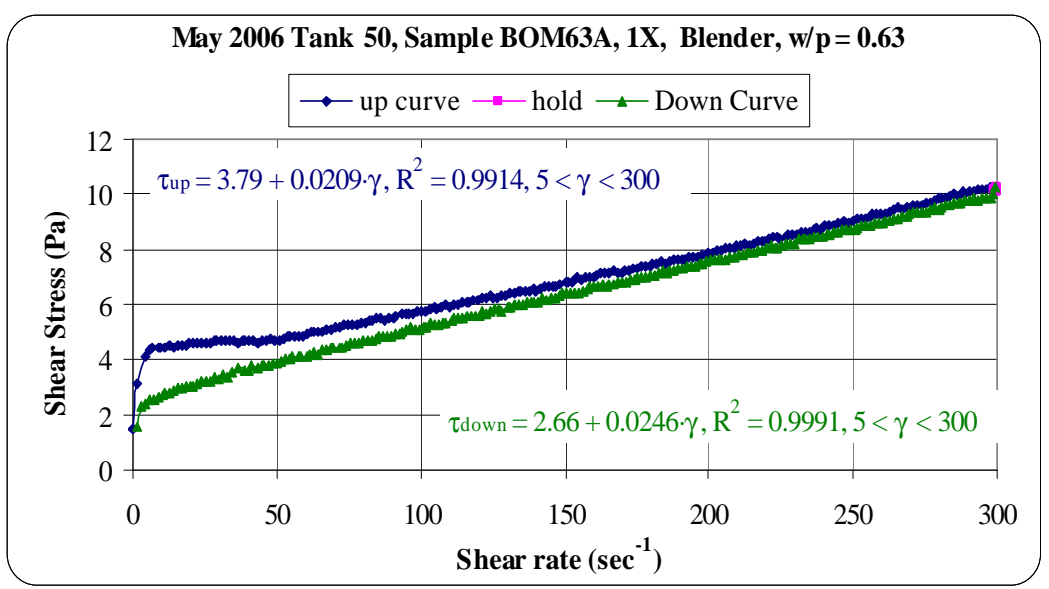

(b)

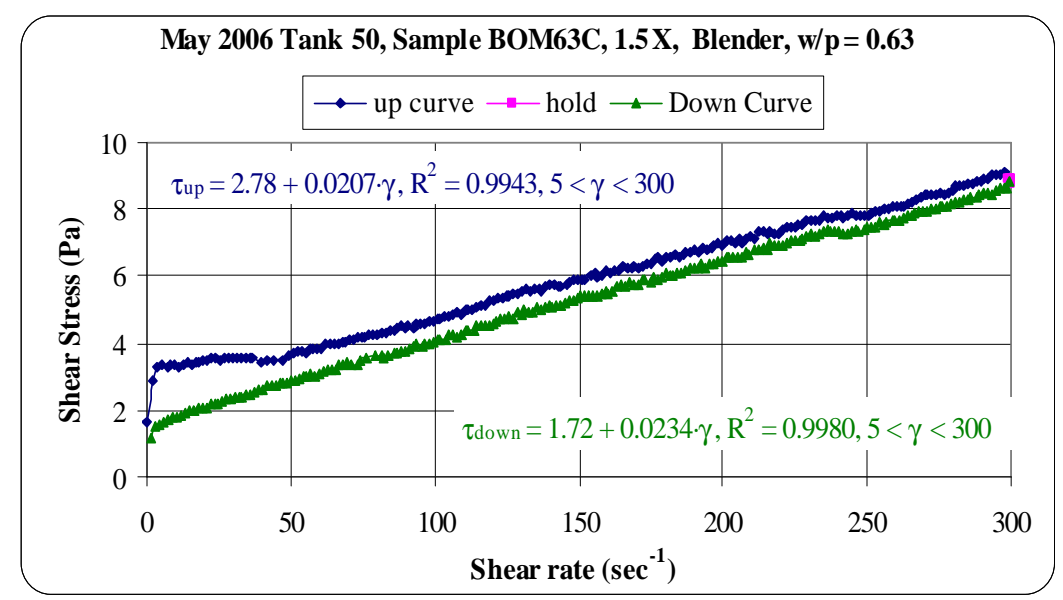

(d)

Figure 3-1. Flow curves for (a) Baseline mix prepared with Tank 50 Batch 0 sample collected in September 2005 and for test mixes with water/premix $=0.63(\mathrm{~b}, \mathrm{c}$, and d) prepared with Tank 50 Batch 0 sample collected in May 2006 with Daratard 17 doses of $1 \mathrm{X}, 2 \mathrm{X}$ and $1.5 \mathrm{X}$, respectively. 
WSRC-TR-2006-00226 Revision 0

June 5, 2006

Page 9 of 19

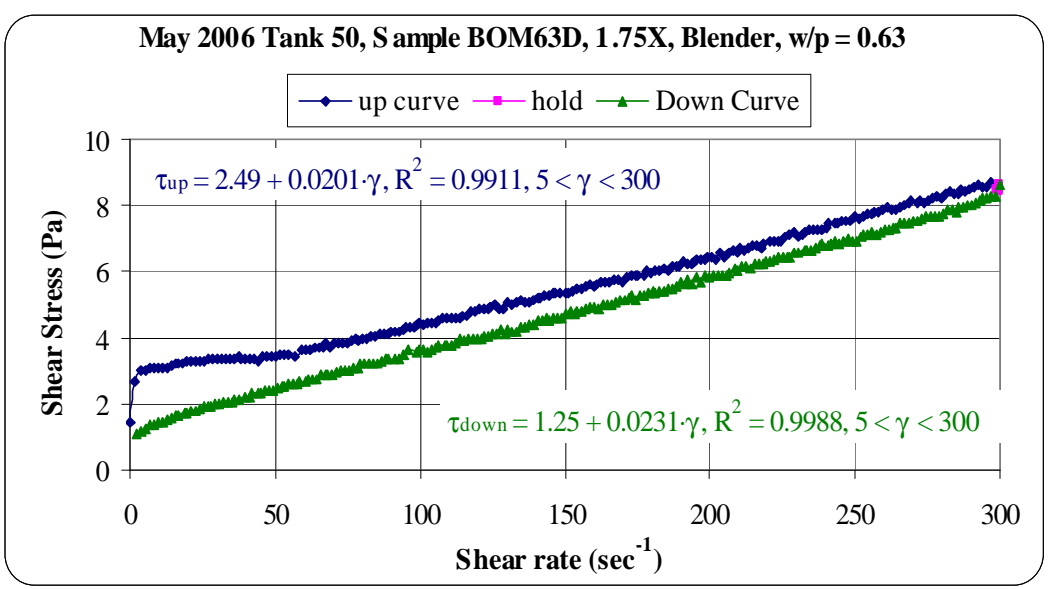

(a)

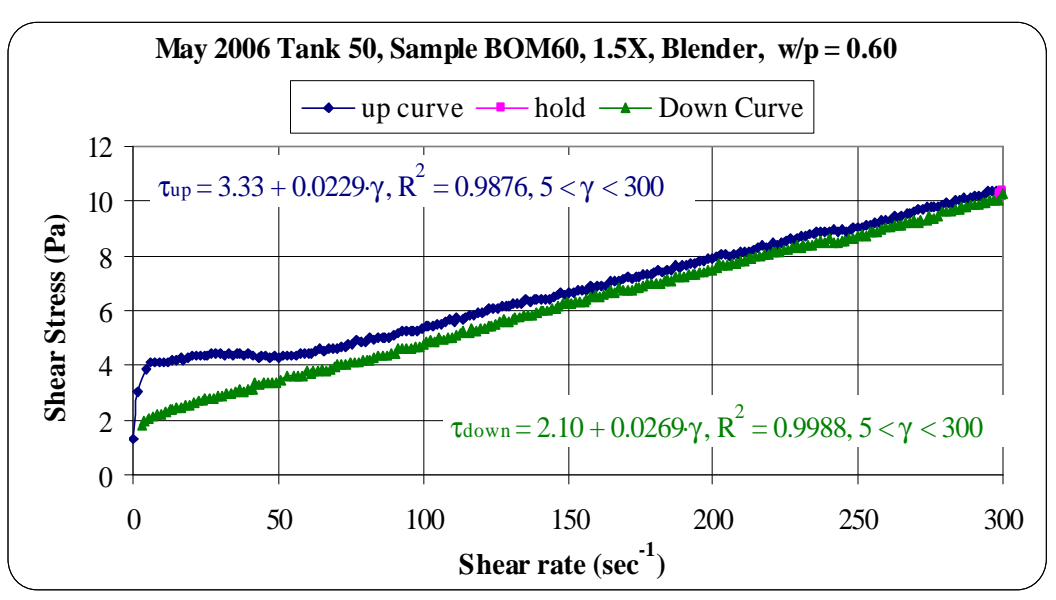

(c)

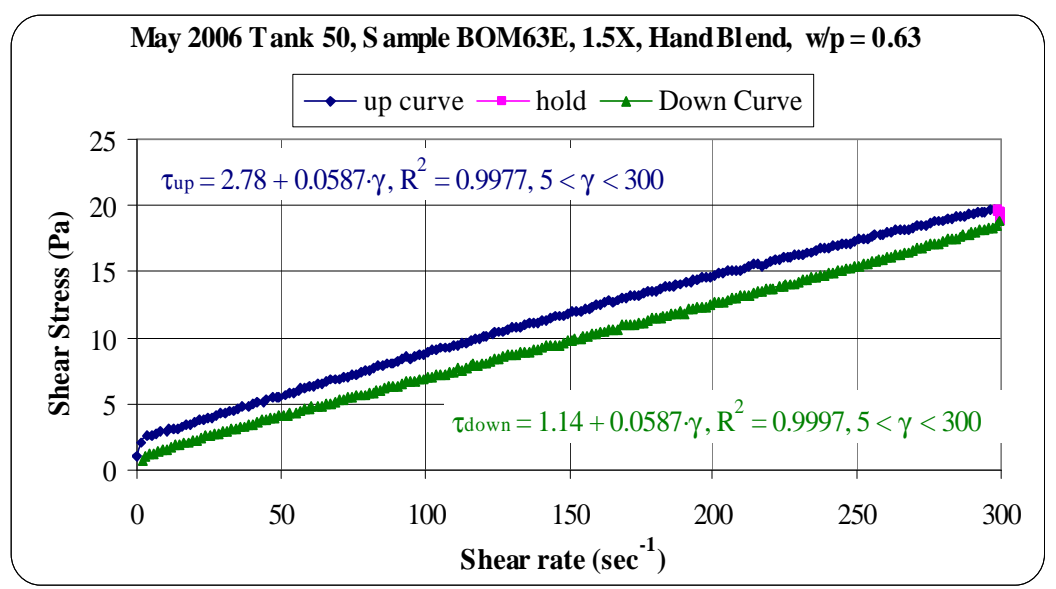

(b)

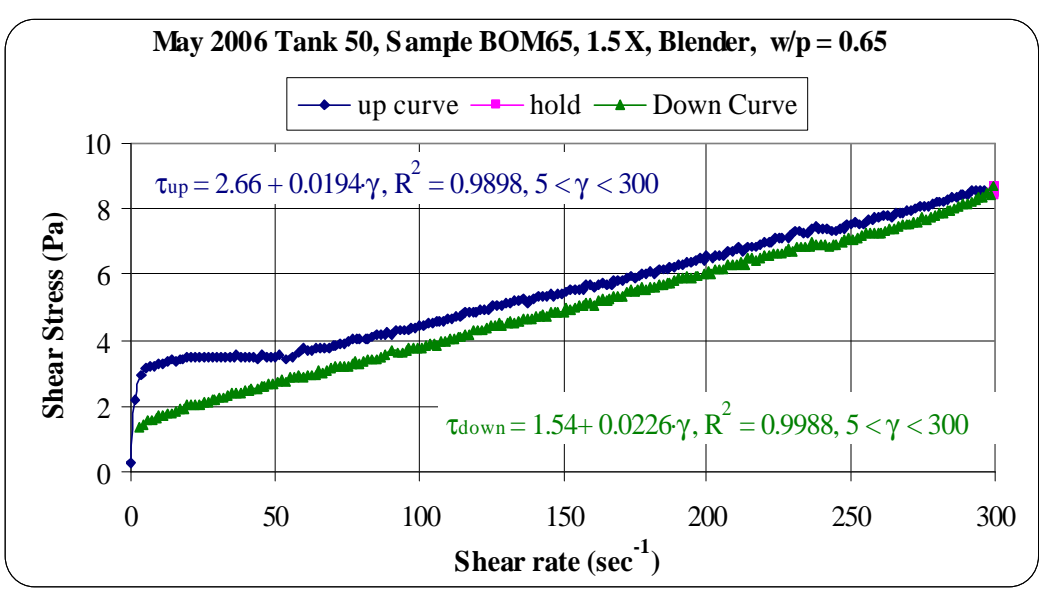

(d)

Figure 3-2. Flow curves for saltstone test mixes prepared with Tank 50 Batch 0 sample collected in May 2006 as a function of Daratard 17 dose, (a) and (b), and as a function of water to premix ratio, (c) and (d). 
Gel times for the test mixes are summarized in Table 3-3. Gel times were estimated by two methods: 1) Vane measurements using the Haake roto viscometer equipped with a four-blade vane (FL22) which was rotated at three revolutions per hour and 2) visual observations of the slurries immediately after mixing and at the end of the vane rheometer test. The time at which the roto viscometer shear stress reached a value of $25 \mathrm{~Pa}$ was selected as the gel time for this study. This correlated with visual observations of inhibited flow due to structure development in the slurry due to gelation or settling or both. Previously, the change in slope of the shear stress versus time curve had been used. The Vane roto viscometer measurements are summarized in Figures 3-3 and 3-4.

Table 3-3. Gel time results for various water/premix ratios and Daratard 17 doses.

\begin{tabular}{|c|c|c|c|c|c|c|}
\hline Sample & $\mathbf{w} / \mathbf{p}$ & $\begin{array}{r}\text { Daratard } 17 \\
\text { (X reference) }\end{array}$ & \begin{tabular}{|c|} 
Clear Air \\
100 \\
(X reference) \\
\end{tabular} & $\begin{array}{c}\text { Gel Time } \\
\text { Visual } \\
\text { (Minutes) } \\
\end{array}$ & $\begin{array}{c}\text { Gel Time } \\
\text { @ 25Pa } \\
\text { Vane }\end{array}$ & Comments \\
\hline $\begin{array}{l}\text { B0S63R } \\
\text { Baseline }\end{array}$ & 0.63 & $\begin{array}{l}0.18 \text { wt. } \% \\
\text { premix } \\
(1 X)\end{array}$ & $\begin{array}{c}0.13 \text { wt. } \% \\
\text { premix } \\
(1 \mathrm{X})\end{array}$ & $\sim 48$ & $\sim 45$ & $\begin{array}{l}\text { Reference } \\
\text { Sept. } 2005 \\
\text { Tank } 50 \text { sample, } \\
\text { Blender }\end{array}$ \\
\hline B0M63A & 0.63 & $\begin{array}{c}0.18 \text { wt. } \% \\
\text { premix } \\
(1 \mathrm{X})\end{array}$ & $\begin{array}{c}\text { Same as } \\
\text { above }\end{array}$ & $<20$ & $\sim 20$ & $\begin{array}{l}\text { May } 2006 \\
\text { Tank } 50 \text { sample, } \\
\text { Blender mixing }\end{array}$ \\
\hline B0M63B & 0.63 & $\begin{array}{l}0.36 \text { wt. } \% \\
\text { premix } \\
(2 \mathrm{X})\end{array}$ & $\begin{array}{c}\text { Same as } \\
\text { above }\end{array}$ & $\sim 90$ & $\sim 90$ & $\begin{array}{l}\text { May } 2006 \\
\text { Tank } 50 \text { sample, } \\
\text { Blender mixing }\end{array}$ \\
\hline В0M63C & 0.63 & $\begin{array}{l}0.27 \text { wt. } \% \\
\text { premix } \\
(1.5 \mathrm{X})\end{array}$ & $\begin{array}{c}\text { Same as } \\
\text { above }\end{array}$ & $\begin{array}{c}\text { Not } \\
\text { Determined }\end{array}$ & $\sim 47$ & $\begin{array}{l}\text { May } 2006 \\
\text { Tank } 50 \text { sample, } \\
\text { Blender mixing }\end{array}$ \\
\hline B0M63D & 0.63 & $\begin{array}{l}0.31 \text { wt. } \% \\
\text { premix } \\
(1.75 \mathrm{X})\end{array}$ & $\begin{array}{c}\text { Same as } \\
\text { above }\end{array}$ & $\sim 85$ & $\sim 72$ & $\begin{array}{l}\text { May } 2006 \\
\text { Tank } 50 \text { sample, } \\
\text { Blender mixing }\end{array}$ \\
\hline B0M63E & 0.63 & $\begin{array}{c}0.27 \mathrm{wt} . \% \\
\text { premix } \\
(1.5 \mathrm{X})\end{array}$ & $\begin{array}{c}\text { Same as } \\
\text { above }\end{array}$ & $<58$ & $\sim 32$ & $\begin{array}{l}\text { May } 2006 \\
\text { Tank } 50 \text { sample, } \\
\text { Hand mixed }\end{array}$ \\
\hline В0M60 & 0.60 & $\begin{array}{l}0.27 \text { wt. } \% \\
\text { premix } \\
(1.5 \mathrm{X})\end{array}$ & $\begin{array}{c}\text { Same as } \\
\text { above }\end{array}$ & $\sim 55$ & $\sim 52$ & $\begin{array}{l}\text { May } 2006 \\
\text { Tank } 50 \text { sample, } \\
\text { Blender mixing }\end{array}$ \\
\hline B0M65 & 0.65 & $\begin{array}{l}0.27 \mathrm{wt} . \% \\
\text { premix } \\
(1.5 \mathrm{X})\end{array}$ & $\begin{array}{c}\text { Same as } \\
\text { above }\end{array}$ & $<60$ & $\sim 52$ & $\begin{array}{l}\text { May } 2006 \\
\text { Tank } 50 \text { sample, } \\
\text { Blender mixing }\end{array}$ \\
\hline
\end{tabular}

Colored shading indicates the Baseline formulation and the formulation using the May 2006 Tank 50 Batch 0 sample that most closely resembles the baseline mix. The baseline mix was made with the September 2005 Tank 50 Sample and the premix prepared with materials obtained from Z-Area in May 2006. 
The effect of Daratard 17 dose on the gel times of saltstone mixes containing a water to premix ratio of 0.63 is illustrated in Figure 6. Results for a saltstone grout made with solution collected from Tank 50 in September 2005, B0S63RV, with a water to premix ratio of 0.63 and a sample made by stirring in a beaker rather than mixing in a blender are also provided for comparison. The stirred sample containing a 1.5X Daratard 17 dose gelled in about 32 minutes compared to about 47 minutes for a sample mixed in the blender.

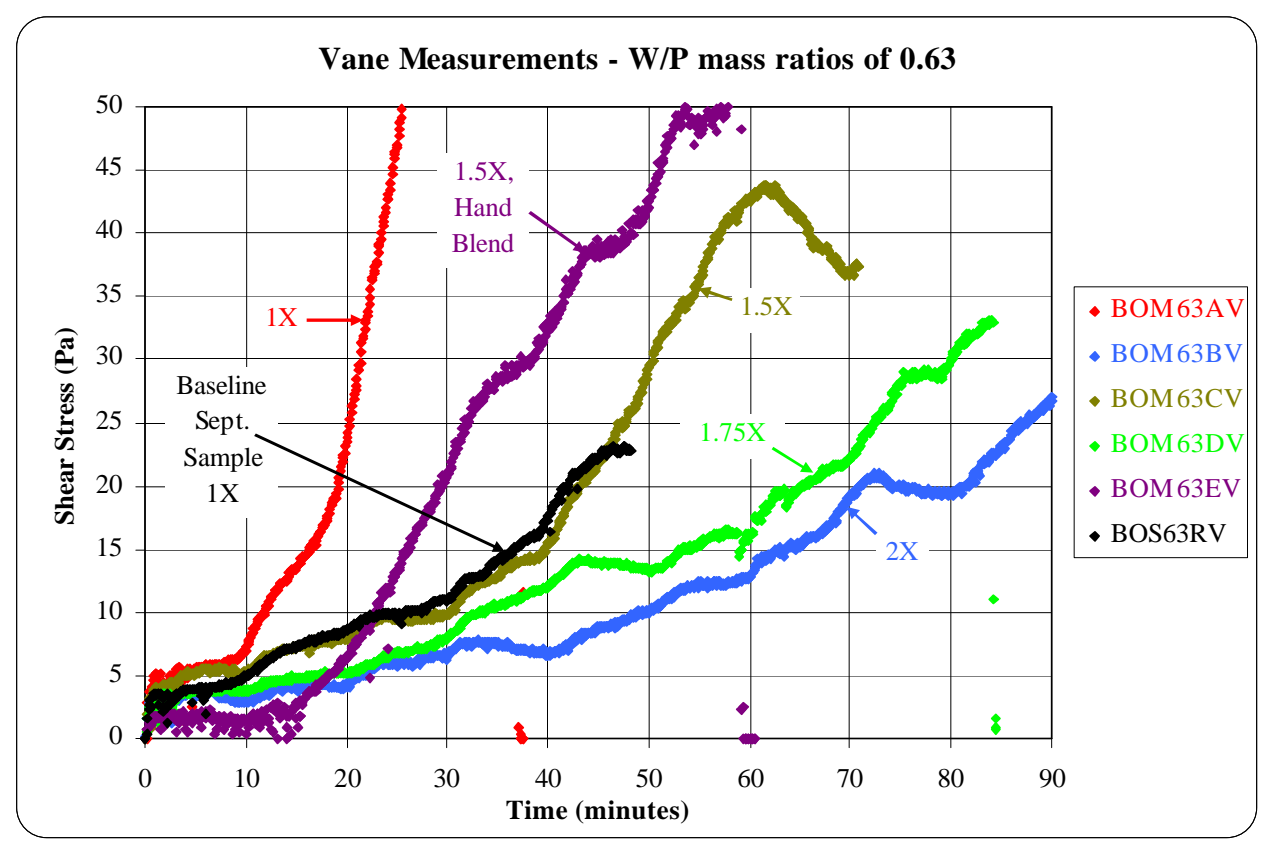

Figure 3-3. Vane measurements using a roto viscometer data for saltstone slurries prepared with the May 2006 Tank 50 Batch 0 solution and a water/premix ratio of 0.63 as a function of Daratard 17 dose.

The effects of water to premix ratio on the gel times of mixes containing a $1.5 \mathrm{X}$ dose of Daratard 17 are illustrated in Figure 3-4. The development of gel structure as indicated by the shear stress versus time curves for mixes with water to premix ratios of $0.60,0.63$ and 0.65 are very similar for the first 50 minutes. The mix with a water to premix ratio of 0.63 gelled in about 48 minutes whereas the other two reached a shear stress of $25 \mathrm{~Pa}$ at about 52 minutes. The mix stirred in a beaker with a water to premix ratio of 0.63 and Daratard 17 dose of $1.5 \mathrm{X}$, B0M63EV, gelled in 32 minutes which is significantly faster than the corresponding mix, B0M63CV, prepared in the blender.

Visual observations of the initial and final flow properties of the mixes are documented in Figure 3-5. 


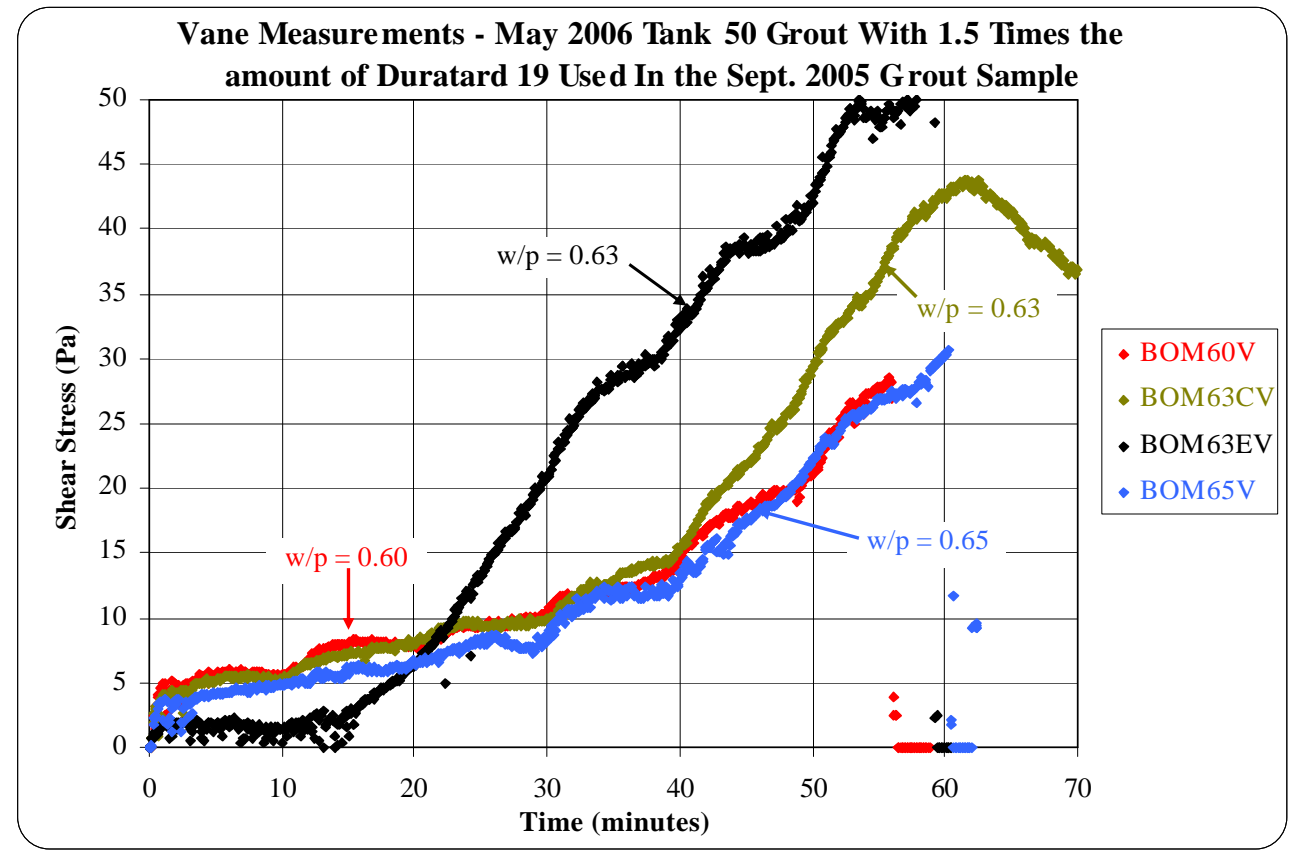

Figure 3-4. Vane measurements using a roto viscometer data for saltstone slurries prepared with the May 2006 Tank 50 Batch 0 solution and a Daratard dose of $1.5 \mathrm{X}$ as a function of water/premix ratio. 
WSRC-TR-2006-00226 Revision 0

June 5, 2006

Page 13 of 19

Figure 3-5. Visual observations of mixes immediately after mixing and after termination of the Vane gel time measurements.

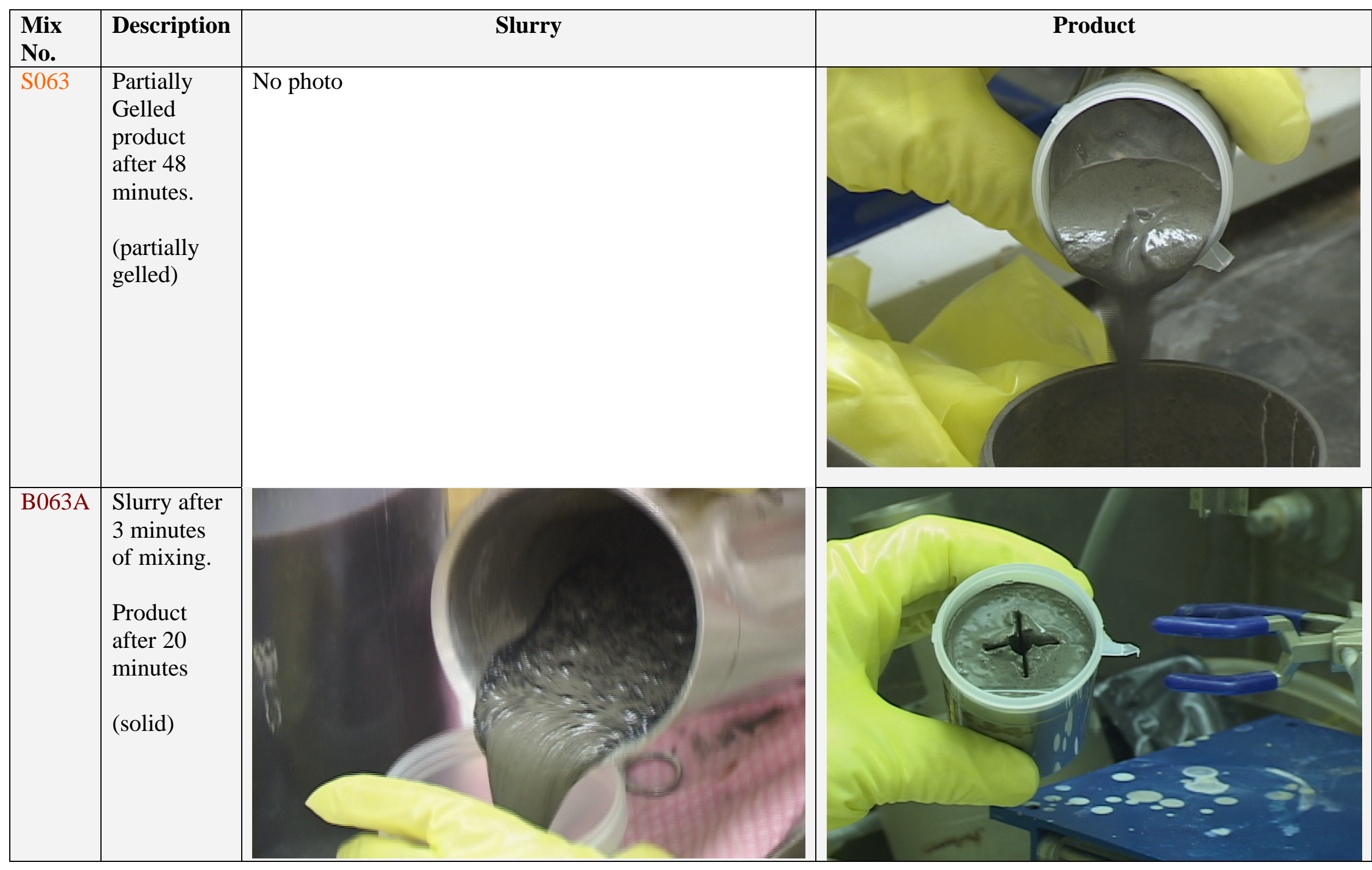


WSRC-TR-2006-00226 Revision 0

June 5, 2006

Page 14 of 19

Figure 3-5 (continued). Visual observations of mixes immediately after mixing and after termination of the Vane gel time measurements.

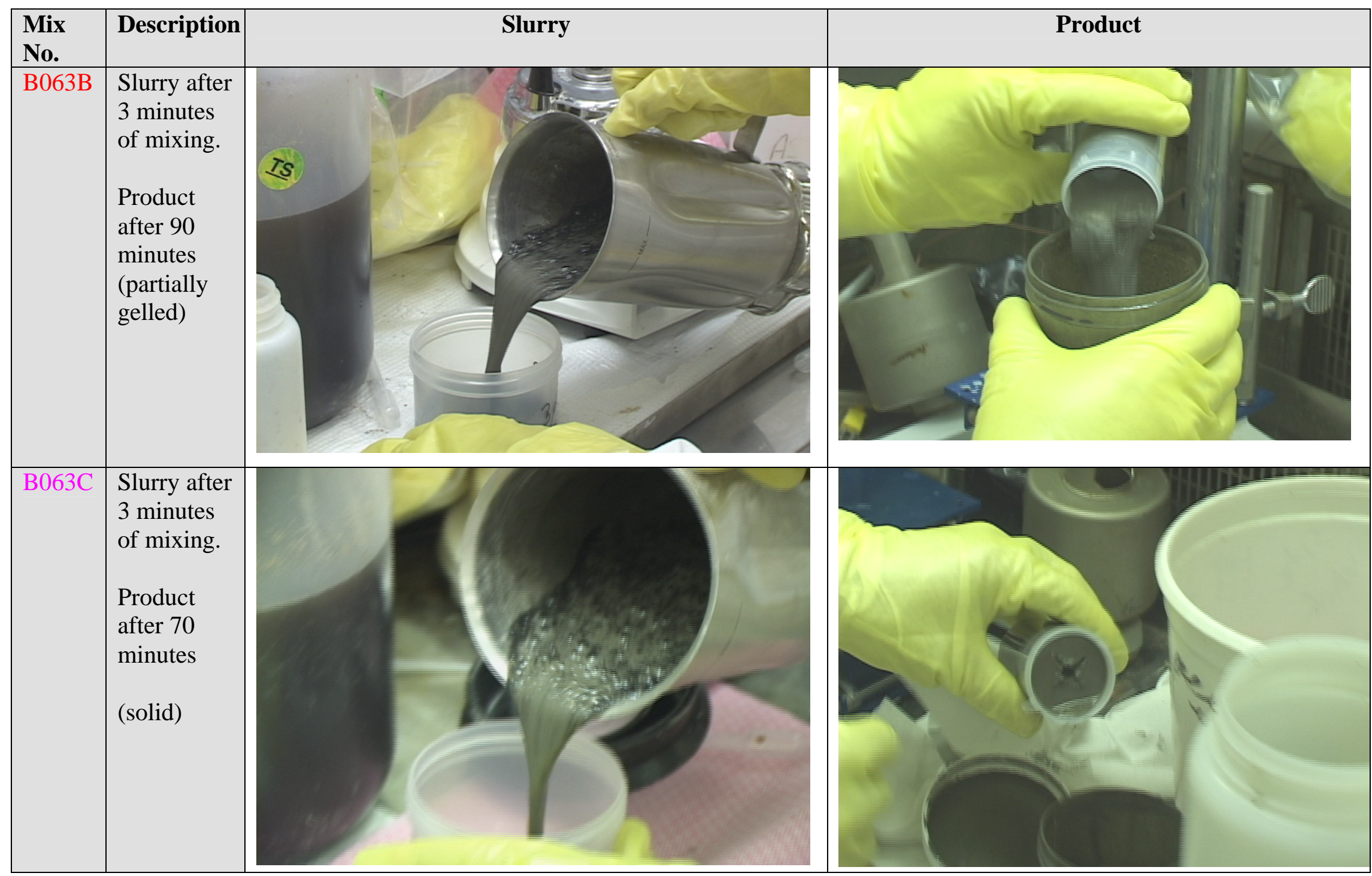


WSRC-TR-2006-00226 Revision 0

June 5, 2006

Page 15 of 19

Figure 3-5 (continued). Visual observations of mixes immediately after mixing and after termination of the Vane gel time measurements.

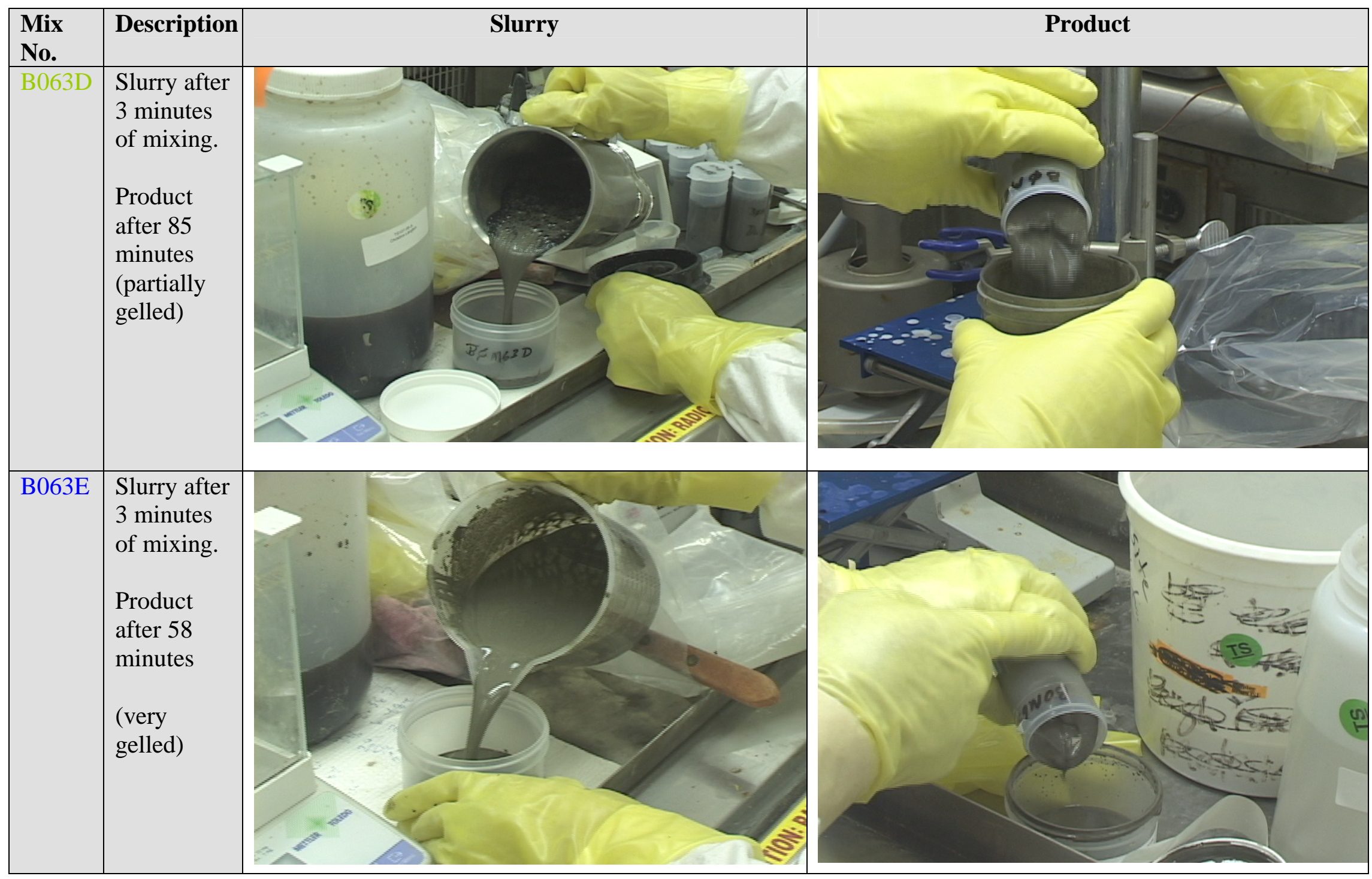


WSRC-TR-2006-00226 Revision 0

June 5, 2006

Page 16 of 19

Figure 3-5 (continued). Visual observations of mixes immediately after mixing and after termination of the Vane gel time measurements.

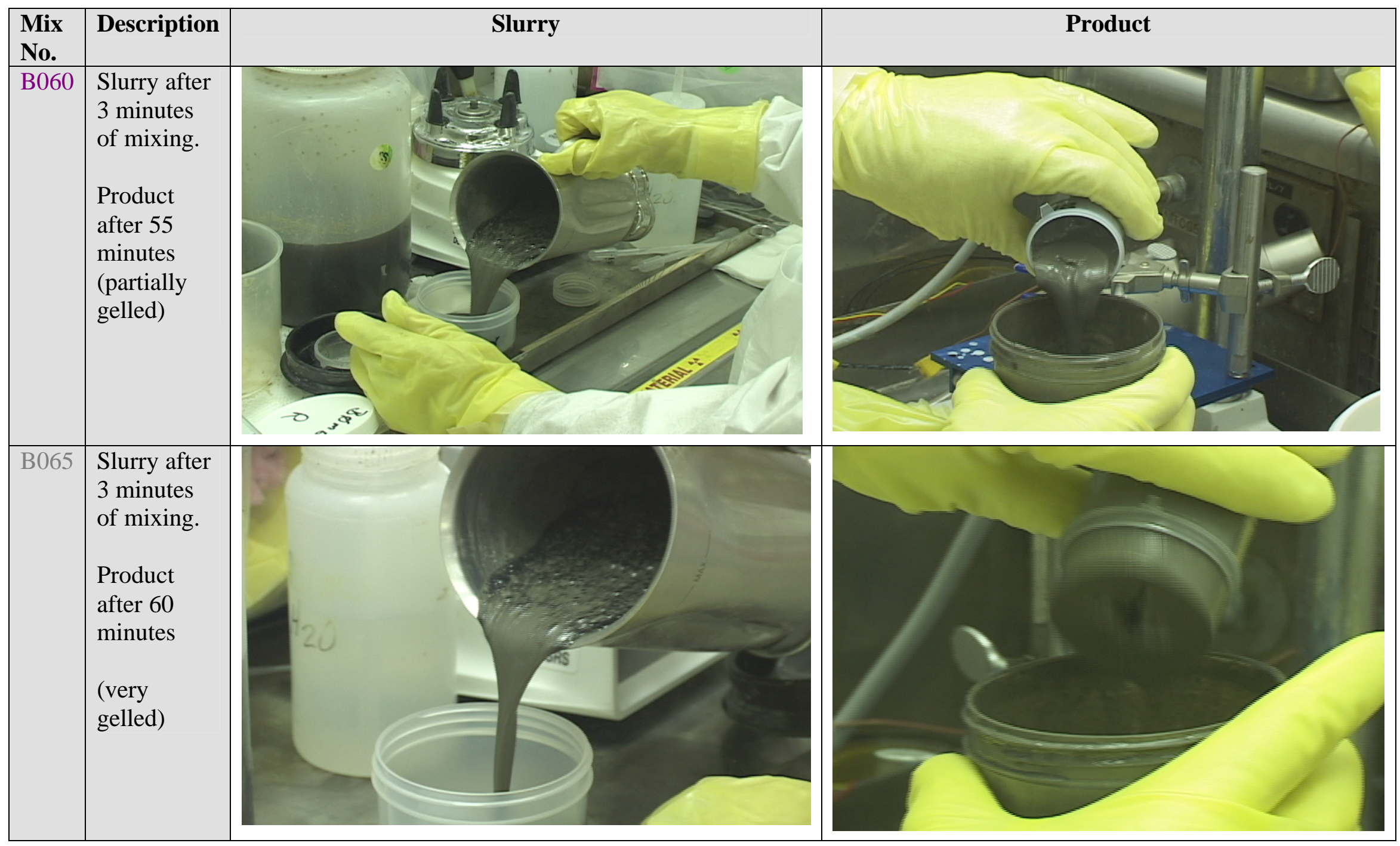




\subsubsection{Saltstone Density, Set Time, and Bleed Water}

Density, bleed water (bleed salt solution) as a function of time, and set time data are summarized for the Tank 50 Batch 0 test mixes in Table 3-4.

Table 3-4. Density, Bleed Water, and Set Time Results for Tank 50 Batch 0 Saltstone Test Mixes.

\begin{tabular}{|c|c|c|c|c|c|c|c|c|}
\hline Sample & $\mathbf{w} / \mathbf{p}$ & $\begin{array}{l}\text { Daratard } 17 \\
\text { (X reference) }\end{array}$ & $\begin{array}{c}\text { Clear Air } \\
100 \\
\text { (X reference) }\end{array}$ & $\begin{array}{c}\text { Slurry } \\
\text { Density } \\
(\mathrm{g} / \mathrm{ml})\end{array}$ & $\begin{array}{r}\text { B } \\
\text { 1day* }\end{array}$ & $\begin{array}{l}\text { eed Wa } \\
\text { (vol.\%) } \\
2 \text { days* }\end{array}$ & $\begin{array}{l}\text { er } \\
5 \text { days }\end{array}$ & $\begin{array}{c}\text { Set Time } \\
\text { (days) }\end{array}$ \\
\hline $\begin{array}{l}\text { B0S63 } \\
\text { Reference }\end{array}$ & 0.63 & $\begin{array}{l}0.18 \mathrm{wt} . \% \\
\text { premix } \\
(1 \mathrm{X})\end{array}$ & $\begin{array}{l}0.13 \mathrm{wt} . \% \\
\text { premix } \\
(1 \mathrm{X})\end{array}$ & 1.702 & 6.8 & 4.3 & 3.2 & $\begin{array}{l}\text { Set within } \\
\sim 2.5 \text { days }\end{array}$ \\
\hline B0M63A & 0.63 & $\begin{array}{l}0.18 \text { wt. } \% \\
\text { premix } \\
(1 \mathrm{X})\end{array}$ & $\begin{array}{c}\text { Same as } \\
\text { above }\end{array}$ & 1.73 & 0 & 0 & 0 & $\begin{array}{c}\text { Set within } \\
3 \text { days }\end{array}$ \\
\hline B0M63B & 0.63 & $\begin{array}{l}0.36 \text { wt. } \% \\
\text { premix } \\
(2 \mathrm{X})\end{array}$ & $\begin{array}{c}\text { Same as } \\
\text { above }\end{array}$ & 1.742 & 6.9 & 6.4 & 4.5 & $\begin{array}{c}\text { Set within } \\
3 \text { days }\end{array}$ \\
\hline B0M63C & 0.63 & $\begin{array}{l}0.27 \text { wt. \% } \\
\text { premix } \\
(1.5 \mathrm{X})\end{array}$ & $\begin{array}{c}\text { Same as } \\
\text { above }\end{array}$ & 1.78 & 4.4 & 3.8 & 1.5 & $\begin{array}{c}\text { Set within } \\
3 \text { days }\end{array}$ \\
\hline B0M63D & 0.63 & $\begin{array}{c}0.315 \text { wt. } \% \\
\text { premix } \\
(1.75 \mathrm{X})\end{array}$ & $\begin{array}{l}\text { Same as } \\
\text { above }\end{array}$ & 1.79 & 2.9 & 2.4 & 0 & $\begin{array}{c}\text { Set within } \\
3 \text { days }\end{array}$ \\
\hline B0M63E & 0.63 & $\begin{array}{l}0.27 \text { wt. } \% \\
\text { premix } \\
(1.5 \mathrm{X}) \\
\end{array}$ & $\begin{array}{l}\text { Same as } \\
\text { above }\end{array}$ & 1.80 & 5.9 & 5.7 & 3.0 & $\begin{array}{c}\text { Set within } \\
3 \text { days }\end{array}$ \\
\hline B0M60 & 0.60 & $\begin{array}{l}0.27 \text { wt. } \% \\
\text { premix } \\
(1.5 \mathrm{X})\end{array}$ & $\begin{array}{l}\text { Same as } \\
\text { above }\end{array}$ & $\begin{array}{c}\text { Not } \\
\text { measured }\end{array}$ & 2.8 & 2.6 & 0 & $\begin{array}{c}\text { Set within } \\
3 \text { days }\end{array}$ \\
\hline B0M65 & 0.65 & $\begin{array}{c}0.27 \text { wt. } \% \\
\text { premix } \\
(1.5 \mathrm{X}) \\
\end{array}$ & $\begin{array}{c}\text { Same as } \\
\text { above }\end{array}$ & $\begin{array}{c}\text { Not } \\
\text { measured }\end{array}$ & 1.0 & 0.6 & 0 & $\begin{array}{c}\text { Set within } \\
3 \text { days }\end{array}$ \\
\hline
\end{tabular}




\subsection{CONCLUSIONS AND RECOMMENDATIONS}

The saltstone formulation developed for the September 2005 Tank 50 Batch 0 sample was confirmed for the May 2006 sample with one minor exception. Saltstone prepared with the Tank 50 sample collected in May 2006 required up to 1.5 times more Daratard 17 set retarding admixture $(0.27$ wt. \% of the premix) than the saltstone prepared with the September 2005 sample to achieve similar gel times for water to premix ratios between 0.60 and 0.65 .

The amount of Daratard 17 and the water to premix ratio should be adjusted during the first processing runs to achieve processability while minimizing bleed water. Although processibility of the May 2006 sample of Tank 50 Batch 0 was confirmed by this testing, the new saltstone pumping system and unique Batch 0 waste characteristics make correlation between the slurry properties measured in the laboratory less precise in optimizing field properties than previous laboratory testing which was supported by numerous hours of operating experience.

This conclusion is based on the observed impact of particle dispersion achieved by two different mixing techniques. Slurries prepared at low speed, low shear mixing (stirring with a spatula) had a higher plastic viscosity $(57 \mathrm{cP})$ than samples made with higher shear mixing in a blender $(23 \mathrm{cP})$. The static gel times of the saltstone slurries made with low shear mixing were also shorter than those for comparable samples made in the blender.

The addition of the various waste streams (ETP, HEU-HCAN, and GPE-HCAN) to Tank 50 from September 2005 to May 2006 resulted in the need to increase the amount of set retarder, Daratard 17, required for processing saltstone slurries through the Saltstone facility. If these streams are continued to be added to Tank 50, the quantity of admixtures required to maintain the same processing conditions for the Saltstone facility will probably change and additional testing is recommended to reconfirm the Tank 50 saltstone formulation.

The Drying Oven Method for determining the weight percents solids and the Guy Lussac Bottle Method for measuring densities of the composite and supernate are more accurate than the Moisture Analyzer Method and calibrated syringe method, respectively, and should be used for slurry characterization. The Moisture Analyzer results used in this study to rapidly estimate the weight percent solids/water in the composite sample are adequate for the saltstone salt solution to premix proportioning calculations. However, in the future, additional time should be allowed to obtain overnight drying oven data. 


\subsection{QUALITY ASSURANCE}

Calibrated equipment and test instruments were used to perform the work described in this report. The tasks were performed in accordance with the SRNL Conduct of Research and Development Manual and results and relevant information are recorded in Notebook WSRCNB-2006-00077.

\subsection{REFERENCES}

1. Staub, A. V., 2006. "Confirmation of Saltstone Grout Formulation for Batch 0," Technical Task Request, SSF-TTR-2006-0001, April 6, 2006, Washington Savannah River Company, Aiken SC 29801.

2. Langton, C. A., P. R. Burket, E. K. Hansen, D. T. Herman, D. M. Marsh, T. K. Snyder, and J. G. Wheeler, 2006. "Tank 50 Batch 0 Saltstone Formulation Testing," WSRC-RP2006-00594, January 30, 2006, Washington Savannah River Company, Aiken SC 29801.

3. Langton, C. A., 2006. “Task Technical and QA Plan: Tank 50 Batch 0 Saltstone Formulation Verification," WSRC-RP-2006-00594, May 4, 2006, Washington Savannah River Company, Aiken SC 29801.

4. CST-2006-00016, 2006. “CST Sample Request Form, requested May 11, 2006, Washington Savannah River Company, Aiken SC 29801.

5. E. K. Hansen, 2005. "Physical Characterization of FY2004 Saltstone Simulant Slurries," WSRC-TR-2005- 00365 Revision 0, December 2005, Washington Savannah River Company, Aiken SC 29801. 
Distribution

T. E. Chandler, 704-Z

A. D. Cozzi, 999-W

K. P. Crapse, 773-43A

D. A. Crowley, 773-A,

R. E. Edwards, 773-A

J. R. Harbour, 773-42A

H. D. Harmon, 766-H

M. W. Loibl, 704-Z

J. E. Marra, 773-A

J. E. Occhipinti, 704-S

J. W. Ray, 704-S

A. V. Staub, 704-27S

P. C. Suggs, 766-H

D. G. Thompson, 704-Z

File: 2 copies 